\title{
Sustainable perennial pastures in Northland
}

\author{
G.R. USSHER ${ }^{1}$ and D.E. HUME ${ }^{2}$ \\ ${ }^{I}$ Clover Consultancy, R. D. 3, Kaitaia \\ ${ }^{2}$ AgResearch, Grasslands Research Centre, Private Bag 11008, Palmerston North \\ cloverconsult@xtra.co.nz
}

\begin{abstract}
In the northern half of Northland, perennial ryegrassbased pastures have exhibited poor persistence. Nineteen tall fescue and ryegrass pastures in the region infected with either MaxP or AR37 fungal endophytes, respectively, had high levels of endophyte-infected tillers and low levels of contamination from wild endophytes. On surveyed farms, MaxP-infected tall fescue pastures had good contents of sown grass, which were higher than sown grass contents in AR37-infected ryegrass pastures, but on two far-north monitor farms these temperate grasses failed to compete with summer active $\mathrm{C} 4$ grasses such as kikuyu and carpet grass. For tall fescue and perennial ryegrass to form productive pastures in this region, sown seed should have high levels of viable endophyte, soil fertility should be adequate for good grass and legume growth, and pastures should be well managed. Summer droughts may still be too severe in some years for these temperate grasses to persist in the face of $\mathrm{C} 4$ grass competition.
\end{abstract}

Keywords: Endophyte, Epichloë, Neotyphodium, Lolium perenne, Festuca arundinacea, soil fertility

\section{Introduction}

The Aupouri Peninsula stretches north of Kaitaia, from Awanui to Cape Regina. Within this district of Northland, there has been widespread farmer dissatisfaction with the persistence of pastures based on perennial ryegrass (Lolium perenne) and white clover (Trifolium repens). Other areas of Northland can also suffer from poor persistence of perennial ryegrassbased pastures. In this region, poor persistence can be due to a range of stresses, including summer-autumn drought, summer heat, competition from aggressive summer-active $\mathrm{C} 4$ grasses, pugging damage during wet winters and high insect challenge (e.g., black beetle (Heteronychus arator)).

In New Zealand, there is considerable evidence that fungal endophyte (Epichloë festucae var. lolii) infection of perennial ryegrass can be crucial in determining productivity and persistence of the grass host (Popay et al. 1999). This occurs primarily through protecting pastures from insect attack, and as a consequence, improving the overall ability of the pasture to survive stresses such as drought (Popay \& Hume 2011). The advantages of endophyte infection in Northland are well documented in both small plot research trials and on farms. Old perennial ryegrass pastures in Northland are typically infected with standard endophyte at a high rate (95-99\%) (Hume et al. 2009), which indicates the important role endophyte has in determining pasture persistence in this environment (Hume \& Barker 2005). In a series of small plot agronomic trials at Kerikeri, Hume et al. (2009) reported that endophyte infection improved yields, relative to endophyte-free grass, within the first 1-2 years of sowing. Selected (novel) endophytes, which have been developed to reduce or eliminate endophyte toxicoses caused by the Standard (syn. Wild-type) endophyte (Stewart et al. 2014), had varying agronomic performance in these trials, with AR37 generally demonstrating superior agronomic performance to Standard and AR1 endophytes.

Under climatic and insect pressure, tall fescue (Festuca arundinacea) is known for its resilience and advantages over perennial ryegrass (Easton et al. 1994). There has been limited use of tall fescue in New Zealand, and Northland is no exception. Reasons for this are varied (e.g., slow establishment, careful grazing management needed to maintain pasture quality, adequate soil fertility; Easton et al. 1994), and may include the lack of endophyte (E. coenophiala) in cultivars sown in the past (Young et al. 2013). Similar to ryegrass, infection of tall fescue with a selected endophyte has been shown to greatly improve its productivity and persistence in Northland (Hume et al. 2009).

In order to investigate the perenniality of temperate grass pastures, interested farmers formed the Aupouri Peninsula Grass Group and set up a project in the northern half of Northland to:

- investigate the establishment of perennial grassbased pastures

- monitor factors impacting on the persistence of perennial grass-based pastures.

With the knowledge of the impact of endophyte and species of temperate grass, the project focused on perennial ryegrass pastures infected with AR37 and tall fescue infected with MaxP endophyte. 


\section{Methods}

Endophyte-infected perennial grasses were established in the autumns of 2011 and 2012 on a monitor dairy farm and a monitor beef and sheep farm in the Aupouri Peninsula of northern Northland. In separate paddocks, three pasture mixes of certified seed were sown; (1) cv. 'Base' tetraploid perennial ryegrass infected with AR37 endophyte, (2) cvs. 'Easton' or 'Quantum II' tall fescue infected with MaxP (AR542) endophyte, and (3) cv. 'Nui' perennial ryegrass. All pastures were sown with white clover. These pastures were monitored for approximately 3.5 years, being assessed for pasture composition and persistence, endophyte presence and type, and soil fertility and moisture.

In addition, on-farm surveys over a wider area of Northland (south of Aupouri Peninsula) were undertaken in spring (September to November) 2011 and autumn (April and May) 2012 of established MaxP-infected tall fescue and endophyte-infected (predominately AR37) perennial ryegrass pastures, respectively. Farmers were also surveyed for their views on endophyte.

Endophyte presence was determined typically on 140-160 tillers per paddock using tissue-print immunoblot (Simpson et al. 2012) and 30 endophyteinfected tillers typed for endophyte strain using a DNAbased SSR assay (Card et al. 2014).

\section{Results and Discussion \\ Monitor farms \\ Soil fertility and moisture}

The monitor dairy farm had a peat soil with high soil fertility for the whole period of monitoring (June 2011 to November 2014), for example, ranges were 59-76 ppm Olsen P, 7-21 K quick test units (QTU) and $\mathrm{pH}$ 5.4-5.7, all within recommended ranges for a peat soil.
A typical yearly application of soil nutrients per ha was $117 \mathrm{~kg} \mathrm{~N}, 30 \mathrm{~kg} \mathrm{P}, 60 \mathrm{~kg} \mathrm{~K}$ and $57 \mathrm{~kg} \mathrm{~S}$.

On the sheep and beef monitor farm, the peaty sand soil had low soil fertility. Prior to cultivation, the $\mathrm{pH}$ was 6.4 , but was only 5.3 when measured 6 months after sowing as very infertile acid soil had been brought to the surface during seedbed preparation. Liming had lifted this $\mathrm{pH}$ to 6.1 by 3.5 years after sowing, but $\mathrm{P}$ (6-12 ppm Olsen P) and K (3-7 QTU) were below recommended ranges throughout the study. A single paddock was sown with 'Easton' MaxP tall fescue on a free-draining Houhora sand with adequate $\mathrm{pH}(5.8-6.5)$ and Olsen P (27-35 ppm) for good pasture growth, but $\mathrm{K}$ was below recommended levels (2-4 QTU).

In each summer-autumn, pastures suffered from drought, with soil moisture levels being close to or below permanent wilting point. On the sand and peatsand soils of the sheep and beef farm, moderate stress (17\% soil moisture) occurred on the 10-month old pastures in late summer 2011/12 when there was 30 days without rain. In March 2013, soils became very dry due to a 100 day period of very low rainfall, with $5-6 \%$ soil moisture content. These same pastures suffered another severe stress period in March 2014 when soil moisture was $5-14 \%$. Soil moisture was higher on the dairy farm but still reached very low levels for a peat soil of $15 \%$ in March 2013 and 26\% in February 2014. At these low levels of soil moisture, field experience has shown that ryegrass, tall fescue and white clover plants will die within Northland pastures.

\section{Endophyte status}

Endophyte testing of the paddocks in late spring 2011, showed that MaxP and AR37 pastures had high proportions of endophyte-infected tillers $(>70 \%)$, and

Table 1 Proportion of endophyte-infected tillers at the two monitor farms for cvs. 'Quantum II' and 'Easton' tall fescue infected with MaxP endophyte, cv. 'Base' perennial ryegrass infected with AR37 endophyte, and cv. 'Nui' infected with Standard endophyte. All pastures were sown in autumn 2011, except for a pasture of 'Easton' MaxP on the sheep and beef farm sown autumn 2012

\begin{tabular}{|c|c|c|c|c|c|c|c|}
\hline & \multicolumn{7}{|c|}{ Endophyte-infected tillers (\%) } \\
\hline & \multicolumn{4}{|c|}{ Sheep and beef farm } & \multicolumn{3}{|c|}{ Dairy farm } \\
\hline & $\begin{array}{c}\text { Tall } \\
\text { fescue- } \\
\text { MaxP }^{1}\end{array}$ & $\begin{array}{c}\text { Tall } \\
\text { fescue- } \\
\text { MaxP }^{2}\end{array}$ & $\begin{array}{c}\text { 'Base' } \\
\text { ryegrass- } \\
\text { AR37 }\end{array}$ & $\begin{array}{c}\text { 'Nui' } \\
\text { ryegrass- } \\
\text { Standard }\end{array}$ & $\begin{array}{c}\text { Tall } \\
\text { fescue- } \\
\text { MaxP }^{1}\end{array}$ & $\begin{array}{c}\text { 'Base' } \\
\text { ryegrass- } \\
\text { AR37 }\end{array}$ & $\begin{array}{c}\text { 'Nui' } \\
\text { ryegrass- } \\
\text { Standard }\end{array}$ \\
\hline Nov 2011 & 72 & & 85 & 5 & 76 & 91 & 11 \\
\hline May 2012 & 83 & & 90 & & 79 & 94 & \\
\hline Nov 2012 & & 90 & & & & & \\
\hline Dec 2013 & 70 & 84 & 85 & & 81 & 90 & \\
\hline Nov/Dec 2014 & 68 & 86 & 89 & & & 92 & \\
\hline
\end{tabular}


these levels were maintained throughout the 3.5 years of monitoring (Table 1). Testing of the infected tillers in tall fescue and 'Base' ryegrass pastures in late spring 2011 showed that only MaxP and AR37 endophytes, respectively, were present, with no contamination with Standard endophyte-infected tillers. 'Base' AR37-based pastures continued to be free of Standard endophyteinfected tillers when tested in early summer 2013 and late spring 2014, except for the sheep and beef monitor farm which had $28 \%$ of tillers infected with Standard endophyte in late spring 2014. 'Nui' pastures had a mean of $8 \%$ infected tillers in 2011. 'Nui' tillers were not typed for endophyte strain but this would have been Standard endophyte as 'Nui' has never been sold with selected endophytes.

Table 2 Species composition of pastures sown in autumn 2011 with endophyte-infected AR37-perennial ryegrass or MaxP-tall fescue at the sheep and beef monitor farm and dairy monitor farm on the Aupouri Peninsula

\begin{tabular}{|c|c|c|c|c|}
\hline \multirow[b]{2}{*}{ Pasture species } & \multicolumn{4}{|c|}{$\%$ composition } \\
\hline & April 2012 & July 2013 & April-May 2014 & October-November 2014 \\
\hline & \multicolumn{4}{|c|}{ 'Base' AR37 ryegrass - sheep and beef farm } \\
\hline Perennial ryegrass & 55 & 20 & 17 & 10 \\
\hline Carpet grass ${ }^{1}$ & 15 & 38 & 50 & 30 \\
\hline Other grasses & 10 & 15 & 5 & 15 \\
\hline Legumes & 5 & 3 & 8 & 17 \\
\hline Toad rush $^{2}$ & 10 & 0 & 14 & 15 \\
\hline \multirow{2}{*}{ Other weeds } & 5 & 24 & 5 & 13 \\
\hline & \multicolumn{4}{|c|}{ 'Quantum II' MaxP tall fescue - sheep and beef farm } \\
\hline Tall fescue & 45 & 25 & 5 & 18 \\
\hline Perennial ryegrass & 0 & 0 & 0 & 15 \\
\hline Carpet grass & 15 & 35 & 70 & 27 \\
\hline Other grasses & 20 & 18 & 17 & 8 \\
\hline Legumes & 10 & 2 & 0 & 17 \\
\hline Toad rush & 0 & 12 & 8 & 0 \\
\hline \multirow[t]{2}{*}{ Other weeds } & 10 & 8 & 0 & 15 \\
\hline & \multicolumn{4}{|c|}{ 'Base' AR37 ryegrass - dairy farm } \\
\hline Perennial ryegrass & 60 & 50 & 10 & 25 \\
\hline Annual ryegrass ${ }^{3}$ & 0 & 0 & 0 & 35 \\
\hline Kikuyu & 15 & 25 & 75 & 15 \\
\hline Poa annua & 0 & 20 & 10 & 15 \\
\hline White clover & 15 & 2 & 5 & 10 \\
\hline \multirow[t]{2}{*}{ Weeds } & 10 & 3 & trace & trace \\
\hline & \multicolumn{4}{|c|}{ 'Quantum II' MaxP tall fescue - dairy farm } \\
\hline Tall fescue & 50 & 45 & 15 & 27 \\
\hline Perennial ryegrass & 6 & 5 & 0 & 10 \\
\hline Annual ryegrass & 0 & 0 & 0 & 35 \\
\hline Kikuyu & 35 & 35 & 80 & 10 \\
\hline Poa annua & 0 & 8 & 0 & 10 \\
\hline White clover & 10 & 5 & 5 & 8 \\
\hline Broad leaf weeds & 5 & 2 & trace & trace \\
\hline
\end{tabular}

${ }^{1}$ Axonopus fissifolius

2 Juncus bufonius

${ }^{3}$ Lolium multiflorum 


\section{Pasture performance}

In all cases, pasture establishment was very good, but pugging damage (in some cases severe) occurred in the first autumn/winter. In addition, pastures on the dairy farm were overgrazed (residual of $1200 \mathrm{~kg} \mathrm{DM} /$ ha, $2-3 \mathrm{~cm}$ height (equivalent to 5 clicks on a rising plate meter)) in February of the first year, placing a high degree of stress on the new pastures particularly in a period of low soil moisture (Brougham 1960; MacDonald et al. 2011).

The 'Nui' ryegrass did not survive the first 12 months on either farm type, with only a few sparsely spaced ryegrass plants present in these paddocks 1 year after sowing. Given the results from endophyte agronomic trials in Northland (Hume et al. 2009), it is highly likely the very low rate of endophyte infection was the cause of the poor persistence of these 'Nui' pastures. Observations of these paddocks suggests damage from Argentine stem weevil (Listronotus bonariensis) was the most likely cause of the very short term life of this perennial ryegrass, while the MaxP and AR37 paddocks suffered no damage (Alison Popay pers. comm). Both certified and uncertified 'Nui' seed sold for use in pastures have no requirement to be tested for endophyte and there are no standards for seed storage to maintain high levels of viable endophyte (Shaun Monk pers. comm.). Without a recent viable endophyte test, 'Nui' seed therefore represents a risk in terms of sowing nil/low endophyte seed that will ultimately result in low ryegrass yields and poor ryegrass persistence.

Over the 3 years, both the 'Base' perennial ryegrass and the tall fescue cultivars declined in their contribution to the pastures on both farm types but to the greatest extent on the sheep and beef farm (Table 2 ). On the sheep and beef property, the ryegrass and tall fescue made up just 10 and $18 \%$, respectively, of the pastures 3.5 years after sowing (Table 2), with lowfertility-loving weed species and summer-active grasses dominating. The poor performance of the sown grasses is likely to be due to a combination of pugging, low soil fertility and very dry summers. On the dairy farm, the sown perennial grasses contributed $25-27 \%$ of the pasture 3.5 years after sowing, but kikuyu (Pennisetum clandestinum) reinvasion was occurring rapidly and dominated pastures in summer-autumn. Pugging in winter and overgrazing in summer of the first year, along with very dry summers, are the likely causes for the poor performance of the sown grasses.

\section{Endophyte in stored seed}

Some seed was stored on farms prior to sowing. Given the importance of endophyte in Northland for pasture persistence, this stored seed was laboratory tested for viable endophyte. For the dairy farm, some seed was stored 5 months (March to August 2014). When tested in August, viable endophyte in 'Base' AR37 ryegrass seed was $80 \%$, which was statistically similar $(\mathrm{P}>0.05)$ to the sown pastures (mean $88 \%$, Table 1), while the MaxP endophyte in tall fescue seed was only $2 \%$ viable and Standard endophyte in 'Nui' $0 \%$ viable. For the sheep and beef farm, tall fescue seed arrived in July 2011, which was too late for sowing. It was stored onfarm until autumn 2012, at which point the seed had no viable endophyte.

These results for Northland support those of Hume et al. (2013), confirming that seed should not be stored on farms at ambient conditions for extended periods. Seed should be obtained from the seed distribution network that uses controlled environment storage facilities to maintain endophyte above the minimum level set by the New Zealand seed industry of $>70 \%$ viable endophyte (Hume \& Barker 2005; Stewart et al. 2014).

\section{Pasture survey \\ Tall fescue}

In spring 2011, tall fescue pastures were surveyed on five farms in Northland, ranging from Dargaville to Kaitaia (Table 3). Pastures averaged 6 years of age and

Table 3 Five Northland tall fescue pastures surveyed in spring 2011 for proportion of endophyte-infected tall fescue tillers, pasture composition and soil Olsen $\mathrm{P}$

\begin{tabular}{lccccccc}
\hline $\begin{array}{l}\text { Farm } \\
\text { location }\end{array}$ & $\begin{array}{c}\text { Soil } \\
\text { Description }\end{array}$ & Topography & $\begin{array}{c}\text { Farm } \\
\text { type }\end{array}$ & $\begin{array}{c}\text { Pasture } \\
\text { age } \\
\text { (years) }\end{array}$ & $\begin{array}{c}\text { Endophyte- } \\
\text { infected } \\
\text { tillers (\%) }\end{array}$ & $\begin{array}{c}\text { Tall fescue } \\
\text { contribution to } \\
\text { pasture cover (\%) }\end{array}$ & $\begin{array}{c}\text { Soil OIsen } \\
\mathbf{P}(\mathbf{p p m})\end{array}$ \\
\hline Kaitaia & Peat & Flat & Dairy & 5 & 83 & 75 & 21 \\
Okaihau & Semi-Volcanic & Flat & Beef & 5 & 86 & 60 & 61 \\
Kerikeri & Semi-Volcanic & Rolling & Dairy & 4 & 86 & 75 & 32 \\
Kawakawa & Clay & Flat & Dairy & 8 & 75 & 70 & 54 \\
Dargaville & Peat & Flat & Dairy & 8 & 91 & 66 & 46 \\
\hline
\end{tabular}

${ }^{1}$ first year post-conversion to dairy 
were predominately dairy operations with high soil fertility (e.g., mean 43 ppm Olsen P). The proportion of endophyte-infected tall fescue tillers was high (mean $84 \%$ ), and all the tillers typed for endophyte strain confirmed the presence of the sown MaxP strain. None of the tillers had the wild-type strain of tall fescue endophyte that can occur in Northland pastures which can be toxic to livestock (Easton et al. 1994). Quite importantly, these pastures had good contents of tall fescue (mean 66\% tall fescue; Table 3), with low levels of weed species (data not shown). These results contrast to poor persistence of tall fescue at Omapere Station, Kaikohe, but the tall fescue lacked endophyte and was grown in a paddock with declining soil fertility (Gavin Ussher unpubl. data). In the environments covered by these localities, and given equivalent soil types and fertility, it is rare to have high persistence of ryegrass ( $>50 \%$ of pasture composition) $5-8$ years after sowing, making tall fescue with a selected endophyte a preferred species to sow in comparison with perennial ryegrass.

\section{Ryegrass}

In the nine perennial ryegrass pastures surveyed, endophyte infection was high (mean 86\%) (Table 4). Most pastures were true to the sown endophyte type with no or low contamination with Standard endophyte with one exception (48\%). Endophyte contamination is possible through several routes (Hume \& Barker 2005), so these results are not unexpected. Soil fertility was generally high (data not shown).

Pasture composition (Table 4) was assessed during a period when kikuyu growth was still strong and paspalum (Paspalum dilatatum) growth was slowing. Given these conditions, a mean content of $30 \%$ ryegrass was not unexpected, and ryegrass content in late winter would have been much higher. The pasture with just $10 \%$ ryegrass was on the most drought-prone soil of the nine farms.

The majority of the farmers rated the establishment of the ryegrass highly. Their views on subsequent production after the establishment period were not as positive, but the majority of farmers felt that ryegrass with AR37 and NEA2 (1 pasture) were persisting well, with drought being the greatest cause of poor persistence of ryegrass. Most of the farmers started using AR37-infected ryegrasses, and have continued to do so, because of a previous lack of persistence of other endophyte-infected ryegrasses in the past. Farmers commented that it is essential to use endophyte in Northland for plant persistence.

\section{Conclusions}

This study has provided good evidence that tall fescue and perennial ryegrass pastures can be established in this region with selected endophytes, and these

Table 4 Nine Northland pastures sown to perennial ryegrass and white clover as surveyed in autumn 2012 for proportion of endophyte-infected ryegrass tillers, endophyte strain, and pasture composition

\begin{tabular}{|c|c|c|c|c|c|c|c|c|c|c|c|c|}
\hline \multirow[b]{2}{*}{$\begin{array}{l}\text { Farm } \\
\text { Location }\end{array}$} & \multirow[b]{2}{*}{$\begin{array}{c}\text { Soil } \\
\text { Description }\end{array}$} & \multirow[b]{2}{*}{$\begin{array}{l}\text { Topo- } \\
\text { graphy }\end{array}$} & \multirow[b]{2}{*}{$\begin{array}{l}\text { Farm } \\
\text { type }\end{array}$} & \multirow[b]{2}{*}{$\begin{array}{c}\text { Pasture } \\
\text { age } \\
\text { (years) }\end{array}$} & \multirow[b]{2}{*}{$\begin{array}{c}\text { Sown } \\
\text { strains of } \\
\text { endophyte }\end{array}$} & \multirow[b]{2}{*}{$\begin{array}{c}\% \\
\text { endophyte } \\
\text {-infected } \\
\text { tillers }\end{array}$} & \multicolumn{5}{|c|}{ Endophyte strain ( $\%$ of infected tillers) } & \multirow[b]{2}{*}{$\begin{array}{l}\text { Perennial } \\
\text { ryegrass } \\
\text { contribution } \\
\text { to pasture } \\
\text { cover }(\%)\end{array}$} \\
\hline & & & & & & & $e^{A R 1}$ & Endo5 & AR37 & NEA2 & Standard & \\
\hline Kaitaia & $\begin{array}{c}\text { Sand - free } \\
\text { draining }\end{array}$ & Flat & Beef & 5 & AR37 & 95 & & & 85 & & 15 & 10 \\
\hline Kaitaia & Clay & Hill & Beef & 4 & AR37 & 78 & & 4 & 96 & & & 20 \\
\hline Kerikeri & Alluvial clay & Flat & $\begin{array}{l}\text { Beef \& } \\
\text { Sheep }\end{array}$ & 4 & AR1, Endo5 & 93 & 52 & 34 & & & 14 & 30 \\
\hline Kerikeri & Clay & Rolling hill & Beef & 3 & AR37 & 67 & & & 100 & & & 45 \\
\hline Kaikohe & Silty clay & Flat & Dairy & 5 & NEA2 & 85 & & & & 100 & & 60 \\
\hline Kaikohe & Clay & Flat & Dairy & 4 & AR37 & 82 & 3 & & 97 & & & 30 \\
\hline Kaikohe & Clay & Rolling hill & Dairy & 6 & AR37 & 89 & & & 100 & & & 25 \\
\hline Dargaville & $\begin{array}{l}\text { Sand - free } \\
\text { draining }\end{array}$ & Easy rolling & Dairy & 4 & AR37 & 88 & & & 90 & & 10 & 30 \\
\hline \multirow[t]{2}{*}{ Dargaville } & $\begin{array}{l}\text { Sand - } \\
\text { podzol }\end{array}$ & Flat & Beef & 8 & AR37 & 97 & & & 52 & & 48 & 25 \\
\hline & & & Mean & 5 & & 86 & & & 89 & & & 30 \\
\hline
\end{tabular}


endophytes are maintained in the pastures over many years. The poor persistence of the low endophyte 'Nui' ryegrass illustrates how important endophyte is for good agronomic performance, and farmers should ensure sown seed has high viable endophyte. Considering the environmental stresses in this region, selected endophytes with the best pest protection profile should be utilised. Endophyte is only one component of good performance of tall fescue and ryegrass pastures, and farmers also need to ensure soils are of good fertility and pastures are well managed by avoiding winter pugging and summer overgrazing. Tall fescue proved to be a better performer than perennial ryegrass, but when drought stress was severe in consecutive years immediately after establishment, and grazing management and soil fertility were sub-optimal, both grass species were dominated by summer active $\mathrm{C} 4$ grasses.

\section{ACKNOWLEDGEMENTS}

The authors thank the Ministry for Primary Industries Sustainable Farming Fund for providing the majority of funding for this project. Additional funding and in-kind supported was provided by the Hine Rangi Trust, Beef + Lamb New Zealand, Clover Consultancy, Agricom, Farmlands, PGG Wrightson, PGG Wrightson Seeds, T. R. Ellett Agricultural Research Trust, and Ballance Agri-Nutrients. We also wish to thank Paul Harvey (dairy monitor farm) and John Woodward (sheep and beef monitor farm).

\section{REFERENCES}

Brougham, R.W. 1960. The effects of frequent hard grazings at different times of the year on the productivity and species yields of a grass-clover pasture. New Zealand Journal of Agricultural Research 3: 125-136.

Card, S.D.; Faville, M.J.; Simpson, W.R.; Johnson, R.D.; Voisey, C.R.; De Bonth, A.C.M.; Hume, D.E. 2014. Mutualistic fungal endophytes in the Triticeae - survey and description. Microbial Ecology 88: 94106.

Easton, H.S.; Lee, C.K.; Fitzgerald, R.D. 1994. Tall fescue in Australia and New Zealand. New Zealand Journal of Agricultural Research 37: 405-417.
Hume, D.E.; Barker, D.J. 2005. Growth and management of endophytic grasses in pastoral agriculture. pp. 201-226. In: Neotyphodium in CoolSeason Grasses. Eds. Roberts, C.A.; West, C.P.; Spiers, D.E. Blackwell Publishing Ltd, Ames, IA.

Hume, D.E.; Card, S.D.; Rolston, M.P. 2013. Effects of storage conditions on endophyte and seed viability in pasture grasses. pp. 405-408. In: Proceedings of the 22nd International Grassland Congress.

Hume, D.E.; Cooper, B.M.; Panckhurst, K.A. 2009. The role of endophyte in determining the persistence and productivity of ryegrass, tall fescue and meadow fescue in Northland. Proceedings of the New Zealand Grassland Association 71: 145-150.

MacDonald, K.A.; Matthew, C.; Glassey, C.B.; McLean, N. 2011. Dairy farm systems to aid persistence. Pasture Persistence Symposium. Grassland Research and Practice Series 15: 199-209

Popay, A.J.; Hume, D.E. 2011. Endophytes improve ryegrass persistence by controlling insects. In: Pasture Persistence Symposium. Grassland Research and Practice Series 15: 149-156

Popay, A.J.; Hume, D.E.; Baltus, J.G.; Latch, G.C.M.; Tapper, B.A.; Lyons, T.B.; Cooper, B.M.; Pennell, C.G.; Eerens, J.P.J.; Marshall, S.L. 1999. Field performance of perennial ryegrass (Lolium perenne) infected with toxin-free fungal endophytes (Neotyphodium spp.). Ryegrass Endophyte: An Essential New Zealand Symbiosis. Grassland Research and Practice Series 7: 113-122.

Simpson, W.R.; Schmid, J.; Singh, J.; Faville, M.J.; Johnson, R.D. 2012. A morphological change in the fungal symbiont Neotyphodium lolii induces dwarfing in its host plant Lolium perenne. Fungal Biology 116: 234-240.

Stewart, A.; Kerr, G.; Lissaman, W.; Rowarth, J. 2014. Endophyte in ryegrass and tall fescue. Pasture and forage plants for New Zealand. Grassland Research and Practice Series 8: 66-77.

Young, C.A.; Hume, D.E.; McCulley, R.L. 2013. Fungal endophytes of tall fescue and perennial ryegrass: Pasture friend or foe? Journal of Animal Science 91: 2379-2394. 